\title{
Effect of Intermittent Warming and Modified Atmosphere Packaging on Fungal Growth in Peaches
}

\author{
J. P. Fernández-Trujillo, M. C. Salmerón, and F. Artés, Postharvest and Refrigeration Laboratory, Food Science \\ and Technology Department, C.E.B.A.S. - C.S.I.C. PO Box 4195, 30080 Murcia, Spain
}

\begin{abstract}
Fernández-Trujillo, J. P., Salmerón, M. C., and Artés, F. 1997. Effect of intermittent warming and modified atmosphere packaging on fungal growth in peaches. Plant Dis. 81:880-884.

Firm-breaker peaches (Prunus persica cv. Paraguayo), treated with $0.25 \mathrm{~g} \cdot$ liter $^{-1}$ iprodione, were inoculated with $10^{6}$ spores per $\mathrm{ml}$ of Alternaria tenuis and stored for up to 3 weeks at $0.5^{\circ} \mathrm{C}$. Three intermittent warming (IW) cycles of 1 day at $20^{\circ} \mathrm{C}$ every 6 days at $0.5^{\circ} \mathrm{C}$ and modified atmosphere packaging (MAP) were applied. Fungicide treatment was ineffective in controlling growth of A. tenuis and Cladosporium spp. during storage. MAP prevented the growth of both fungal genera. IW alone or combined with fungicide seemed to increase total CFU counts and did not control decay (mainly due to exacerbated Cladosporium spp. development). CFU counts and losses through fungal attack were only occasionally significantly correlated.
\end{abstract}

Additional keywords: cold storage, postharvest, Rovral, weight losses

Susceptibility to chilling injury, weight loss, and decay permit only a brief cold storage of peaches. At $0^{\circ} \mathrm{C}$, their shelf-life is about 3 weeks $(20,24)$. Intermittent warming (IW) and modified atmosphere packaging (MAP) have been applied to extend the shelf life of peaches because of the resulting reduction in chilling injuries $(2,4,20)$.

Because of concerns with food safety, there has been a renewal of interest in nonchemical approaches to postharvest disease control (14). For stone fruits, several types of physical treatments as alternatives to fungicides, such as chilling inactivation (27), controlled atmosphere or MAP $(7,22)$, pre-storage heat treatments, individual seal-packaging (5), and combinations of the above, have been applied. Levels of $\mathrm{CO}_{2}$ above $20 \%$ (16) and postharvest chemical treatment are the main strategies for controlling postharvest decay in stone fruits. In particular, iprodione at 1 $\mathrm{g} \cdot$ liter $^{-1}$ was effective against species of Botrytis, Monilinia, Rhizopus, and Penicillium in harvested peaches $(9,10,19)$. A gas composition of 10 to $15 \% \mathrm{O}_{2}$ and 15 to $25 \% \mathrm{CO}_{2}$ within the packages, as generated by conventional MAP, provides a satisfactory retention of quality attributes in peaches (15). However, exposure of fresh produce to levels of $\mathrm{O}_{2}$ or $\mathrm{CO}_{2}$ outside

Corresponding author: F. Artés

E-mail: fr.artes@natura.cebas.csic.es

Accepted for publication 17 April 1997.

Publication no. D-1997-0602-02R

(C) 1997 The American Phytopathological Society their limits of tolerance (depending on peach cultivars, less than $2 \%$ for $\mathrm{O}_{2}$ and up to 15 to $25 \%$ for $\left.\mathrm{CO}_{2}\right)(15,28)$ can increase anaerobic respiration and the development of off flavors and other physiological disorders (15).

The present work was conducted to examine the effectiveness of IW and MAP individually or combined on the reduction of postharvest decay in cold stored peaches treated with iprodione and inoculated with Alternaria tenuis.

\section{MATERIALS AND METHODS}

Firm-breaker peaches (Prunus persica (L.) Batsch 'Paraguayo') were harvested from a commercial orchard in Cieza (Murcia) and transported by an air-conditioned car to a packinghouse (Cofrucieza Soc. Coop., Cieza) where they were sorted and selected for uniform size and appearance and freedom from defects. The mean and standard deviation measurements of the fruit were as follows: axial diameter $\mathbf{4 3 . 2}$ $\pm 1.3 \mathrm{~mm}$; longitudinal diameter $74.2 \pm$ $4.3 \mathrm{~mm}$; and weight $137.4 \pm 14.4 \mathrm{~g}$. Boxes of $5 \mathrm{~kg}$ each were quickly transported by an air-conditioned car to the laboratory at Murcia (35 km from Cieza) where they were immediately precooled in forced air to reach $5^{\circ} \mathrm{C}$ next to the stone $5 \mathrm{~h}$ later and $0.5^{\circ} \mathrm{C} 12 \mathrm{~h}$ later. Temperatures were recorded at 15 -min intervals with a LCD portable thermometer (Digi-Thermo; Tecnoquim, Murcia, Spain) with an external sensing probe inserted at the pit of each of 5 fruit. The following morning, the peaches were arbitrarily divided into batches of 54 fruit, representing three replicates of 18 fruit each. Other fruit were sealed in oriented polypropylene film (30 fruit representing 5 replicates of 6 fruit each).

The mean and standard deviation specifications of the polymeric film (Derfilm 40 DF 300), as provided by the supplier (Derprosa, Madrid, Spain), were 42.5 \pm 3.8 $\mu \mathrm{m}$ thickness and permeabilities of $0.090 \pm$ $0.001 \mathrm{~g} \cdot \mathrm{m}^{-2} \cdot$ day $^{-1}$ to water vapor, 1,112 $\pm 23 \mathrm{~g} \cdot \mathrm{m}^{-2} \cdot$ day $^{-1}$ to $\mathrm{CO}_{2}$ and $290 \pm 14 \mathrm{~g}$. $\mathrm{m}^{-2} \cdot$ day $^{-1}$ to $\mathrm{O}_{2}$ (all values at $83 \%$ relative humidity $[\mathrm{RH}]$ and $5^{\circ} \mathrm{C}$ ).

A postharvest dip treatment with iprodione (Rovral 50WP, Rhône-Poulenc, Paris, France) at $0.25 \mathrm{~g} \cdot \operatorname{liter}^{-1}\left(\mathrm{pH}=7\right.$ and $18^{\circ} \mathrm{C}$ for $5 \mathrm{~min}$ ) was used to study its efficacy when combined with IW and MAP techniques. All fruit used for MAP storage were fungicide treated. Peaches selected for continuous cold storage were placed inside clean plastic boxes with the fruit touching and the boxes then placed inside 360-liter, gas-tight, stainless steel chambers in a cold room at $0.5 \pm 0.5^{\circ} \mathrm{C}$ and $95 \%$ RH. The chambers were equipped with a renewal humidification system with an airflow of 360 liters $\cdot h^{-1}(3)$. During IW storage, three warmings were applied by removing the corresponding boxes and bags from the cold room to another room at $20^{\circ} \mathrm{C}$ and $95 \% \mathrm{RH}$. After 1 day of warming, the fruit were re-transferred to $0.5^{\circ} \mathrm{C}$ (3). The batches of peaches undergoing MAP were placed in the same cold room at $0.5^{\circ} \mathrm{C}$.

Weight loss was determined with a scale with an accuracy of $0.1 \mathrm{~g}$ (Mettler, PJ1220, Madrid, Spain). Changes in $\mathrm{O}_{2}$ and $\mathrm{CO}_{2}$ concentration within the bags were monitored in a gas chromatograph (Perkin Elmer, Autosystem 1020, Madrid, Spain) equipped with a thermal conductivity detector.

A. tenuis was isolated from a rotted Paraguayo peach. A conidial suspension was prepared in sterile, distilled water (10 $\mathrm{g} \cdot$ liter $^{-1}$ ) from a 7-day-old, single-conidium culture grown on Rose Bengal Agar (Adsa-Micro SA, Barcelona, Spain) at $30^{\circ} \mathrm{C}$. The suspension was stirred before and during inoculation to maintain uniform conidial distribution (17). Iprodionetreated fruit were inoculated $5 \mathrm{~h}$ after harvest with a spore suspension of $10^{6}$ spores $\mathrm{ml}^{-1}$ of $A$. tenuis. Initial counts of microorganisms were made $24 \mathrm{~h}$ later, and results were expressed as $\mathrm{CFU}$ per $\mathrm{ml}$.

For the sampling procedure, 6 fruit from each replicate and treatment were aseptically removed, put into a bath of 2.5 liters 
of sterile, distilled water, and shaken vigorously for $30 \mathrm{~s}$. From each replicate, 0.2 $\mathrm{ml}$ of a $10^{-1}$ dilution of this water was transferred to a petri dish (three dishes per replicate). Microflora counts were made after 3 days at $30^{\circ} \mathrm{C}$ and then microscopically examined. In order to identify fungal groups, the macroscopic characteristics of the colonies were observed (color, shape, and firmness) as well as some microscopic characteristics (fruiting type, shape and color of the spores), following the procedure of Barnett and Hunter (8) and Artés et al. (6). Fruit were examined for rot incidence at the beginning of storage and at weekly intervals until 3 weeks of storage.

The experimental design was completely randomized. Each plastic box or each plastic bag constituted a replicate. The percentage of total losses and CFU per ml were statistically analyzed by converting values to their respective $\lambda$ root transformation (11) or arcsine transformation (25), respectively. For the statistical analysis of CFU per $\mathrm{ml}$, the $\lambda$ values were between 0.25 and 0.1 for A. tenuis and between 0.5 and 0.1 for Cladosporium spp. Given the factorial structure of the treatments (conventional cold storage [CS] with or without fungicide [F], IW with or without fungicide, MAP, and $\mathrm{IW}+\mathrm{F}+\mathrm{MAP}$ ), the analysis of variance and residual analysis $(21,25)$ were divided in two sections (I and II). Thus, the statistical model was as follows: $Y_{i j k} \ell=\mu+\mathrm{T}_{i}+\mathrm{IW}_{j}+\mathrm{F}_{k}+\mathrm{T}_{i} \cdot \mathrm{IW}_{j}+$ $\mathrm{IW}_{j} \cdot \mathrm{F}_{k}+\mathrm{T}_{i} \cdot \mathrm{F}_{k}+\mathrm{IW}_{j} \cdot \mathrm{T}_{i} \cdot \mathrm{F}_{k}+\varepsilon\left({ }_{i j k}\right) \ell$, where $Y_{i j k}$ is the th replicate $(\ell=1,2,3)$ of the $i$ th time $(\mathrm{T})(i=0,1,2,3$, in weeks) and $j$ th $\operatorname{IW}(j=0,1)$ and $k$ th fungicide or MAP $(k=0,1)$. If significant differences in time were found, least significant difference or orthogonal polynomial contrasts were performed $(3,21,25)$.

\section{RESULTS AND DISCUSSION}

Identification of microorganisms. Except in MAP-treated fruit, all treatments exhibited symptoms of A. tenuis after 1 week of storage. After 2 weeks of storage, Cladosporium spp. appeared. Cladosporium is a weak parasite that rarely causes loss in cold stored peaches $(13,26)$. The rotted tissue affected by this fungus is confined to the surface of peaches (12), and in our experiment, infections by Cladosporium spp. were superficial, associated mainly with overripe fruit (showing excessive softness and shriveling). The fungus's high rate of growth was probably related to a disruption of its balance with A. tenuis. Other ubiquitous fungal pathogenic species (Rhizopus, Penicillium, and Aspergillus) and yeasts also appeared occasionally but to a lesser extent. In accordance with the terminology used to describe fungal and bacterial growth by sigmoid curves (27), the lag phase of $A$. tenuis growth was similar in all treatments. However, a lag and $\log$ phase of Cladosporium spp.

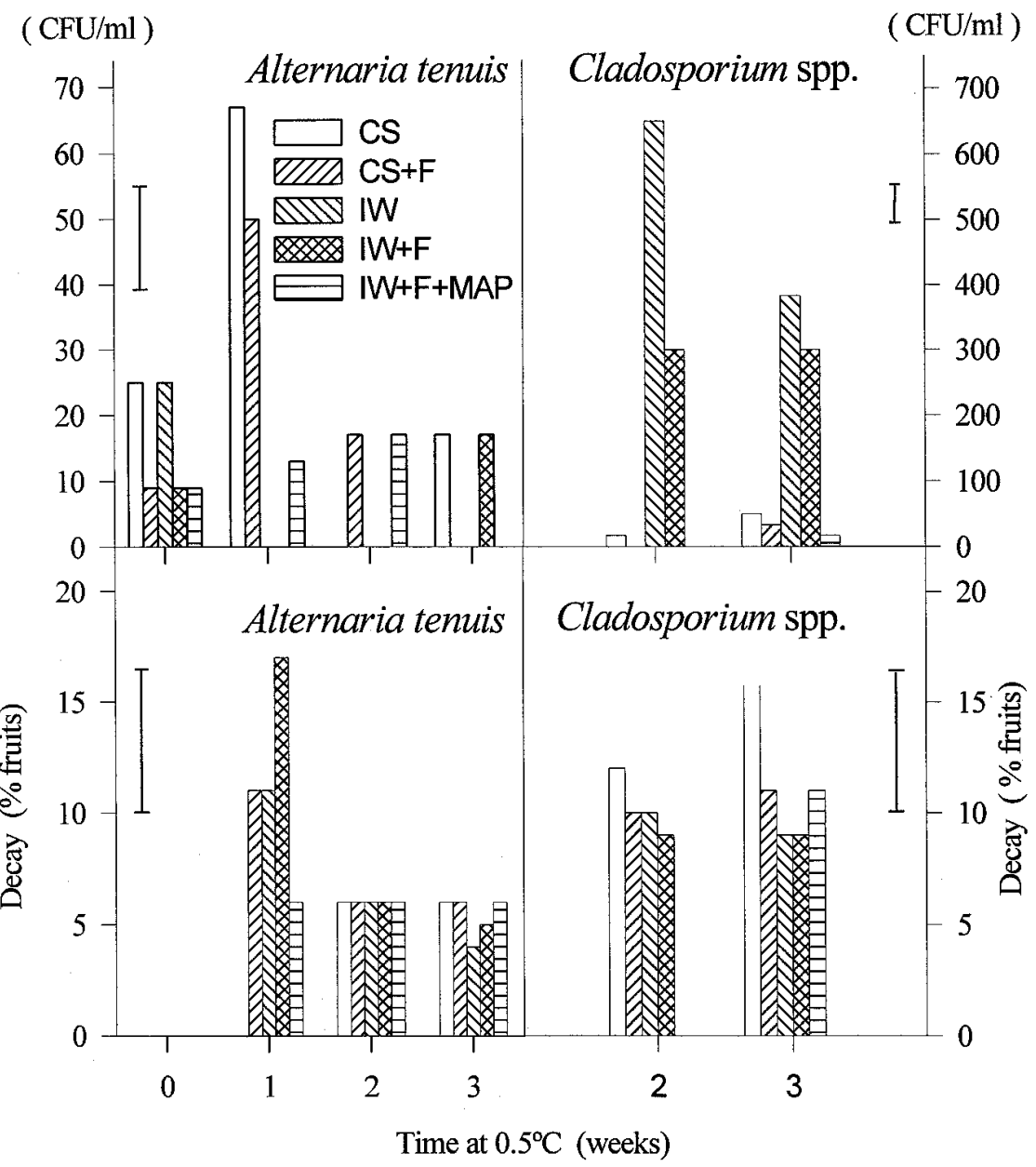

Fig. 1. Means of decay and CFU during storage of peach cv. Paraguayo at $0.5^{\circ} \mathrm{C}$ (no CFU counts and no decay of both fungi genera were observed on modified atmosphere packaging (MAP) plus fungicide treatment at any time; no CFU of Cladosporium spp. at harvest and after 1 week of storage were observed). $\mathrm{CS}=$ conventional storage at $0.5^{\circ} \mathrm{C}$; $\mathrm{CS}+\mathrm{F}=\mathrm{CS}$ with a previous fungicide dip (iprodione, $0.25 \mathrm{~g} \cdot$ liter $^{-1}$ ). IW $=$ intermittent warming, 3 cycles of 1 day at $20^{\circ} \mathrm{C}$ every 6 days at $0.5^{\circ} \mathrm{C}$. Bars are least significant difference at $P=0.05$.

Table 1. Analysis of variance of the CFU and total decay incidence on peaches inoculated with $\mathrm{Al}$ ternaria tenuis and stored in air

\begin{tabular}{|c|c|c|c|c|c|}
\hline \multirow[b]{2}{*}{ Source } & \multirow[b]{2}{*}{$\mathbf{d f} \mathbf{f}^{\mathbf{w}}$} & \multicolumn{2}{|c|}{$\begin{array}{l}\text { Cladosporium spp. } \\
\text { (CFU per ml) }\end{array}$} & \multicolumn{2}{|c|}{ Total decay (\%) } \\
\hline & & $\mathbf{S S}^{\mathrm{x}}$ & $P^{\mathbf{y}}$ & SS & $P$ \\
\hline Intermittent warming (IW) & 1 & 731.2 & $* * *$ & 0.010 & NS \\
\hline Fungicide $(\mathrm{F})$ & 1 & 15.4 & NS & 0.012 & NS \\
\hline Time & 3 & 1263.3 & $* * *$ & 0.653 & $* * *$ \\
\hline Linear effect & 1 & 1042.0 & $* * *$ & 0.293 & $* * *$ \\
\hline Quadratic effect & 1 & 1.4 & NS & 0.307 & $* * *$ \\
\hline Cubic effect & 1 & 219.8 & $* * *$ & 0.053 & NS \\
\hline $\mathrm{IW} \times \mathrm{F}$ & 1 & 1.5 & NS & 0.000 & NS \\
\hline Time $\times$ IW $^{z}$ & 3 & 751.8 & $* * *$ & 0.035 & NS \\
\hline Linear $\times$ IW & 1 & 517.6 & $* * *$ & 0.005 & NS \\
\hline Cubic $\times$ IW & 1 & 223.7 & $* * *$ & 0.011 & NS \\
\hline Time $\times F^{z}$ & 3 & 16.2 & NS & 0.064 & NS \\
\hline Time $\times$ IW $\times F^{z}$ & 3 & 2.6 & NS & 0.157 & $*$ \\
\hline Cubic $\times$ IW $\times$ F & 1 & 0.02 & NS & 0.130 & ** \\
\hline Residual & 32 & 457.2 & & 0.502 & \\
\hline$\%$ variance explained & & & 85.9 & & 65.0 \\
\hline
\end{tabular}


growth was promoted by IW storage, possibly because spore germination was induced by the temperatures applied in the warming phase, which were near the optimum temperature for fungal growth.

Effect on CFU counts. Fungicide treatment reduced the initial CFU counts on the fruit surface (Fig. 1), although during the experiment as a whole, such treatment, with or without IW, had no significant effect on total CFU counts (Table 1). This was probably due to the low concentration $2.4 \mathrm{~g} \cdot$ liter $^{-1}$ of iprodione has been reported as being effective in controlling A. alternata and $A$. mali in apples $(18,23)$.

IW had no effect on the CFU counts of A. tenuis (Fig. 1). After the first warming reach a constant level because development of Cladosporium spp. probably was exacerbated by IW. Following the analyof iprodione used, since a concentration of period, total CFU counts increased to

sis of variance model (Tables 1 and 2), only the linear effect of time was significant $(P=0.01)$ for CFU counts of $A$. tenuis with a low explained variance (35.6 to $41.4 \%$ ). High CFU counts of $C$. herbarum have been reported in apricots with a maximum level after 10 days of storage at $0^{\circ} \mathrm{C}(5)$.

In contrast, MAP alone resulted in no CFU counts and no decay for both $A$. tenuis and Cladosporium spp. (Table 2). Its efficacy was similar when combined with IW (IW+F+MAP treatment), although particularly effective in controlling Cladosporium spp. (Fig. 1 and Table 2).

Effect on weight losses and decay. A high correlation $\left(R^{2}=0.88\right.$ to $0.99, P \leq$ $0.001)$ was found from the linear regression model used to predict weight losses during cold storage (Fig. 2). MAP drastically reduced total weight losses during storage, while IW and IW+F+MAP almost

Table 2. Mean squares from the analysis of variance of the CFU and total decay incidence in peaches inoculated with Alternaria tenuis and treated with $0.25 \mathrm{~g} \cdot$ liter $^{-1}$ iprodione

\begin{tabular}{|c|c|c|c|c|c|}
\hline \multirow[b]{2}{*}{ Source } & \multirow[b]{2}{*}{$d f^{w}$} & \multicolumn{2}{|c|}{$\begin{array}{l}\text { Cladosporium spp. } \\
\text { (CFU per ml) }\end{array}$} & \multicolumn{2}{|c|}{ Total decay (\%) } \\
\hline & & $\mathbf{S S}^{\mathbf{x}}$ & $P^{y}$ & SS & $P$ \\
\hline Intermittent warming (IW) & 1 & 2.215 & $* * *$ & 0.003 & NS \\
\hline MAP & 1 & 2.307 & $* * *$ & 0.087 & $* *$ \\
\hline Time & & 3.787 & $* * *$ & 0.205 & $* * *$ \\
\hline Linear effect & 1 & 3.011 & $* * *$ & 0.111 & $* *$ \\
\hline Quadratic effect & 1 & 0.000 & NS & 0.087 & $* *$ \\
\hline Cubic effect & 1 & 0.753 & $*$ & 0.007 & NS \\
\hline $\mathrm{IW} \times \mathrm{MAP}$ & & 1.127 & ** & 0.003 & NS \\
\hline Time $\times$ IW $^{z}$ & 3 & 2.650 & $* * *$ & 0.052 & NS \\
\hline Linear $\times$ IW & 1 & 1.262 & $* *$ & 0.019 & NS \\
\hline Cubic $\times$ IW & 1 & 1.176 & $* *$ & 0.035 & NS \\
\hline Time $\times \mathrm{MAP}^{\mathrm{z}}$ & 3 & 2.658 & $* * *$ & 0.064 & NS \\
\hline Linear $\times$ MAP & 1 & 2.388 & $* * *$ & 0.013 & NS \\
\hline Quadratic $\times$ MAP & 1 & 0.180 & NS & 0.040 & $*$ \\
\hline Time $\times$ IW $\times \mathrm{MAP}^{\mathrm{z}}$ & 3 & 1.130 & $*$ & 0.033 & NS \\
\hline Linear $\times$ IW $x^{*}$ MAP & 1 & 0.868 & $* *$ & 0.002 & NS \\
\hline Residual & 32 & 3.225 & & 0.274 & \\
\hline$\%$ variance explained & & & 83.1 & & 62.0 \\
\hline
\end{tabular}

Table 3. Analysis of variance of weight losses under conventional storage and modified atmosphere packaging (MAP) of peaches ${ }^{\mathrm{v}}$

\begin{tabular}{|c|c|c|c|c|c|}
\hline \multirow[b]{2}{*}{ Source } & \multirow[b]{2}{*}{$d f^{w}$} & \multicolumn{2}{|c|}{ Conventional } & \multicolumn{2}{|c|}{ MAP } \\
\hline & & $\mathbf{S S}^{\mathbf{x}}$ & $P^{y}$ & SS & $P$ \\
\hline Time & 3 & 28.46 & $* * *$ & 0.469 & $* * *$ \\
\hline Linear effect & 1 & 28.30 & **** & 0.462 & $* * *$ \\
\hline Quadratic effect & 1 & 0.08 & NS & 0.006 & ** \\
\hline Cubic effect & 1 & 0.08 & NS & 0.005 & * \\
\hline Intermittent warming (IW) & 1 & 3.48 & $* * *$ & 0.056 & $* * *$ \\
\hline Time $\times I^{2}$ & 3 & 3.69 & $* * *$ & 0.024 & $* * *$ \\
\hline Linear $\times$ IW & 1 & 3.36 & **** & 0.023 & $*$ \\
\hline Residual & 56 & 9.69 & & 0.041 & \\
\hline$\%$ variance explained & & & 78.6 & & 93.2 \\
\hline
\end{tabular}

${ }^{\mathrm{v}}$ Weight losses as percent on a fresh weight basis (wt/wt).

${ }^{\mathrm{w}}$ Degrees of freedom.

${ }^{x}$ Sum of squares.

y Probability: NS = not significant; * **, ***, significant at $P=0.05,0.01$, or 0.001 , respectively.

${ }^{\mathrm{z}}$ Quadratic and cubic interactions time $\times$ IW were not significant. doubled the values obtained with conventional storage and MAP, respectively (Figs. 1 and 2; Table 3). The effect of IW in air confirms our previous results in other cultivars $(2,4)$. However, in MAP fruit a quadratic trend was detected (Figs. 1 and 2; Table 3). Differences observed between MAP and $\mathrm{IW}+\mathrm{F}+\mathrm{MAP}$ were probably related to the linear effect of increasing weight losses due to IW. The quadratic trend in the MAP fruit response may be related to water vapor accumulation within the unperforated bags during the first week of storage, practically without weight loss.

No significant effect on the efficacy of iprodione dip alone or combined with IW in reducing decay caused by both $A$. tenuis and Cladosporium spp. was observed. IW had no effect in reducing decay by $A$. tenuis or Cladosporium spp. (Fig. 1). Total losses were similar to those observed in conventionally stored fruit due to overripeness (less than 2 and $4 \%$ fruit affected after 2 or 3 weeks of storage, respectively, in IW or IW plus iprodione). In IW fruit, $A$. tenuis and Cladosporium spp. attacked overripe fruit to a greater extent. Iprodione showed no synergistic effect with IW, refuting in part our previous hypothesis (4). It is possible that this synergistic effect might occur at higher concentrations and/ or in more mature fruit, because of different susceptibilities to fungal attack and/or a different degree of resistance to gas diffusion $(3,27,28)$.

MAP prevented the growth of both $A$. tenuis and Cladosporium spp., confirming previous results $(5,15)$. This was probably due to the fungistatic effect of high $\mathrm{CO}_{2}$ generated by passive MAP (19.5 $\pm 2.5 \%$ $\mathrm{CO}_{2}$ and $5.1 \pm 1.6 \% \mathrm{O}_{2}$ means and standard errors, respectively) or $\mathrm{IW}+\mathrm{F}+\mathrm{MAP}$ (where $\mathrm{CO}_{2}$ levels increase temporarily by about $5 \% \mathrm{CO}_{2}$ after every IW period). A synergistic effect between $\mathrm{O}_{2}$ and $\mathrm{CO}_{2}$ in reducing fungal attack is very improbable (1). However, when this effect is combined with IW, a slight growth of both fungal genera was observed, probably due to water condensation within the plastic bags.

According to the hypothesis of BarkaiGolan (7), antifungal compounds that were active in the immature Paraguayo peaches and that decrease with ripening (enhanced by IW in the present work) could be related to changes in fruit resistance against fungal development during IW and MAP. Fungicide treatment, IW, and MAP would only modulate the development of this disruption after inoculation with $A$. tenuis. This disruption of the balance was not found in MAP fruit, probably because of pathogen growth inhibition by high $\mathrm{CO}_{2}$ concentrations.

In conclusion, MAP retarded the onset of senescence, confirming previous results of Barkai-Golan (7), who showed that MAP also inhibited ripening and senescence and probably suppressed the progress of deep-seated infections. This fung- 
istatic effect on CFU counts and decay was probably due to high $\mathrm{CO}_{2}$ levels in MAP. However, the application of IW, which produced a slight and short-term increase in $\mathrm{CO}_{2}$ in the atmosphere, was less efficient in controlling decay than MAP.

The effect of IW in increasing CFU of Cladosporium spp. in air-stored fruit (which has not previously been reported) was well correlated with an increase in decay. However, the growth of A. tenuis was limited. Moreover, low concentrations of iprodione dip had no effect on CFU counts and total losses. High CFU counts and losses by fungal attacks were only occasionally correlated significantly, which is



Fig. 2. Prediction of weight losses (percent on a fresh weight basis at harvest) during different peach storage conditions at $0.5^{\circ} \mathrm{C}$ by linear regression. Continuous storage with or without fungicide (CS and $\mathrm{CS}+\mathrm{F}$, respectively) treatment (open circle); 3 cycles of intermittent warming (IW) of 1 day at $20^{\circ} \mathrm{C}$ every 6 days at $0.5^{\circ} \mathrm{C}$, with or without fungicide (IW and IW+F, respectively) treatment (solid triangle); modified atmosphere packaging (MAP), fruit treated with fungicide, (open triangle), and $\mathrm{IW}+\mathrm{F}+\mathrm{MAP}$ (solid circle). Bars are standard errors of means and arrows below the $x$ axis indicate IW. All equations were significant at $P \leq 0.001$. in agreement with previous findings (6). Further studies are required to clarify possible synergistic effects among IW, fungicide treatments, and peach maturity stage at harvest.

\section{ACKNOWLEDGEMENTS}

The paper was supported by Iltmo. Ayto. de Cieza (Murcia) and Spanish CICYT (ALI-95/0530 Project). J. P. Fernández-Trujillo is indebted to CSIC for his Ph.D. grant; this study is part of the Ph.D. by him. We thank A. Hernández and J. A. Martínez for technical help. Peaches and other facilities were provided by Cofrucieza S. Coop. and Soc. Coop. Agraria Ciezana de Frutas, and films by Derprosa.

\section{LITERATURE CITED}

1. Agar, T., García, J. M., Miedtke, U., and Streif, J. 1994. Effect of high $\mathrm{CO}_{2}$ and low $\mathrm{O}_{2}$ concentrations on the growth of Botrytis cinerea at different temperatures. Gartenbauwissenschaft 55:219-222.

2. Artés, F., Cano, A., and Fernández-Trujillo, J. P. 1996. Pectolytic enzyme activity during intermittent warming storage of peaches. J. Food Sci. 61:311-313, 321.

3. Artés, F., and Escriche, A. J. 1994. Intermittent warming effect on development of chilling injury of tomatoes. J. Food Sci. 59:10531056.

4. Artés, F., Escriche, A. J., Salmerón, M. C., Marín, J. G., and Guzmán, G. 1987. Study of storage and ripening of peach var. 'Maruja' like raw material for canned industry. Proc. Int. Cong. Canned Foods, 9th. 3.1-3.16

5. Artés, F., Martínez, J. A., Escriche, A. J., and Marín, J. G. 1992. Caracterización y cambios de la microflora fúngica de albaricoque 'Real Fino' durante la conservación con y sin envoltura en film plástico. II Cong. Int. Tecn. Des. Alim. 2:133-140.

6. Artés, F., Rodríguez, M. C., Martínez, J. A., and Marín, J. G. 1995. Influence of fungicide treatment and storage conditions on fungal activity of 'Satsuma' mandarin. Int. J. Refrig. 18:63-66

7. Barkai-Golan, R. 1990. Postharvest disease suppression by atmospheric modifications. Pages 237-264 in: Food Preservation by Modified Atmospheres. M. Calderon and R. Barkai-Golan, eds. CRC, Boca Raton, FL.

8. Barnett, H. L., and Hunter, B. B. 1972. Illustrated Genera of Imperfect Fungi. Burgess Pub., Minneapolis.

9. Biggs, A. R., Ingle, M., and Solihati, W. D. 1993. Control of Alternaria infection of fruit of apple cultivar Nittany with calcium chloride and fungicides. Plant Dis. 77:976-980.

10. Bompeix, G., Coeffic, M., Greffier, P. 1979 Lutte contre les pourritures des pêches à Monilia spp., Botrytis spp. et Rhizopus spp. Fruits 34:423-430.

11. Box, G. E. P., and Cox, D. R. 1964. An analysis of transformations. J. Royal Stat. Soc., B, 26:211-243.

12. Bratley, C. O. 1931. Decay of sweet cherries from California. Plant Dis. Rep. 29:559-566.

13. Ceponis, M. J., Cappellini, R. A., Wells, J. M., and Lightner, G. W. 1987. Disorders in plum, peach, and nectarine shipments to the New York market, 1972-1985. Plant Dis. 71: 947-952.

14. De Vries-Paterson, R. M., Jones, A. L., and Cameron, A. C. 1991. Fungistatic effects of carbon dioxide in a package environment on the decay of Michigan sweet cherries by Monilinia fructicola. Plant Dis. 75:943-946.

15. Deily, K. R., and Rizvi, S. S. H. 1981. Optimization of parameters for packaging of fresh peaches in polymeric films. J. Food Process Eng. 5:23-41.

Plant Disease / August 1997883 
16. El-Goorani, M. A., and Sommer, N. F. 1981. Effects of modified atmospheres on postharvest pathogens of fruits and vegetables. Hortic. Rev. 3:412-461.

17. Fallik, E., Klein, J., Grinberg, S., Lomaniec, E., Lurie, S., and Lalazar, A. S. 1993. Effect of postharvest heat treatment of tomatoes on fruit ripening and decay caused by Botrytis cinerea. Plant Dis.77:985-988.

18. Filajdić, N., and Sutton, T. B. 1992. Chemical control of Alternaria blotch of apples caused by Alternaria mali. Plant Dis. 76:126-130.

19. Laville, E., and Souty, M. 1982. Aspects phytopathologiques de la qualité des pêches de la région sud de la France. Essais de traitements après récolte. Fruits 37:301-313.
20. Lill, R. E., O’Donoghue, E. M., and King, G. A. 1989. Postharvest physiology of peaches and nectarines. Hortic. Rev. 11:413-452.

21. Little, T. M. 1981. Interpretation and presentation of results. HortScience 16:637-640.

22. Lurie, S. 1993. Modified atmosphere storage of peaches and nectarines to reduce storage disorders. J. Food Qual. 16:57-65.

23. Manji, B. T., Ogawa, J. M., and Wu, Y. 1991. Postharvest chemical control of $\mathrm{Al}$ ternaria, Botrytis, and Penicillium rot of apples in California. (Abstr.) Phytopathology 81:1345

24. Robertson, J. A., Meredith, F. I., Horvart, R. J., and Senter, S. D. 1990. Effect of cold storage and maturity on the physical and chemi- cal characteristics and volatile constituents of peaches (cv. Cresthaven). J. Agric. Food Chem. 38:620-624.

25. Romero, R., and Zúñiga, L. 1993. Estadística. UPV, Valencia, Spain.

26. Snowdon, A. L. 1990. Stone fruits. Pages 218-237 in: A Colour Atlas of Post-harvest Diseases and Disorders of Fruits and Vegetables. Vol. 1: General Introduction and Fruits. Wolfe Scientific, London.

27. Sommer, N. F. 1982. Postharvest handling practices and postharvest diseases of fruit. Plant Dis. 66: 357-364.

28. Zagory, D., and Kader, A. A. 1988. Modified atmosphere packaging of fresh produce. Food Technol. (Chicago) 42:70-74, 76-77. 